\title{
Assessment of co-benefits of black carbon emission reduction measures in Southeast Asia: Part 2 emission scenarios for 2030 and co-benefits on mitigation of air pollution and climate forcing
}

Didin Agustian Permadi ${ }^{1}$, Nguyen Thi Kim Oanh ${ }^{1 *}$ and Robert Vautard ${ }^{2}$

${ }^{1}$ Environmental Engineering and Management; School of Environment, Resources and Development; Asian Institute of Technology; Klong Luang, Pathumthani 12120, Thailand.

${ }^{2}$ Laboratoire des Sciences du Climate de l'Environment (LSCE), Institut Pierre Simon Laplace (IPSL), Gif Sur Yvette, France.

Correspondence to: Nguyen Thi Kim Oanh (kimoanh@ait.ac.th)

Table S1: Description of mitigation measures for RED2030 Scenario for Indonesia and Thailand Table S2: Summary of projected activity data used for BAU2030

Figure S1: Annual average concentrations of BC and OC obtained from global LMDZ/INCA simulation for 2006 and 2030 and the constructed 2030/2006 ratios for both species

Figure S2: Comparison of sectoral emissions in the BY2007 with BAU2030 and RED2030 scenarios for Indonesia and Thailand 
Table S1: Description of mitigation measures for RED2030 Scenario for Indonesia and Thailand.

\begin{tabular}{|c|c|c|c|}
\hline \multirow{2}{*}{ No } & \multirow{2}{*}{ Sector } & \multicolumn{2}{|c|}{ Description of RED2030 measures } \\
\hline & & Indonesia & Thailand \\
\hline \multirow[t]{2}{*}{1} & \multirow[t]{2}{*}{ Transportation } & $\begin{array}{l}\text { All personal cars would have to comply with } \\
\text { Euro2 in } 2030^{\mathrm{a}}\end{array}$ & $\begin{array}{l}\text { All personal cars }<1,600 \mathrm{CC} \text { in the } \\
\text { market in } 2030 \text { would have fuel } \\
\text { consumption } 5 \text { liters } / 100 \mathrm{~km} \text { and would } \\
\text { comply with Euro } 4 \text { standard }\end{array}$ \\
\hline & & $\begin{array}{l}100 \% \text { of public diesel buses would be shifted } \\
\text { to } \mathrm{CNG}^{\mathrm{b}}\end{array}$ & $\begin{array}{l}\text { Implementation of cleaner fuel of CNG } \\
\text { for all public buses and taxi in } 2030^{\mathrm{f}}\end{array}$ \\
\hline \multirow[t]{2}{*}{2} & \multirow[t]{2}{*}{ Residential } & $\begin{array}{l}\text { Full implementation of "zero kero" program } \\
\text { to cover } 42 \text { million ( } 64 \% \text { ) households } \\
\text { converted from kerosene to LPG by } 2012 \\
\text { and } 80 \% \text { of number of households as end- } \\
\text { point (by 2030) }\end{array}$ & $\begin{array}{l}50 \% \text { of total fuel consumption of wood } \\
\text { and charcoal in } 2030 \text { would be converted } \\
\text { to } \mathrm{LPG}^{\mathrm{f}}\end{array}$ \\
\hline & & $\begin{array}{l}\text { Substitution of traditional fuel wood cook } \\
\text { stoves to cleaner biomass stoves (gasifier } \\
\text { stoves) }\end{array}$ & $\begin{array}{l}\text { Electricity to replace biomass (in } 2030 \\
20 \% \text { of fuel wood would be converted to } \\
\text { electricity) }^{\mathrm{f}}\end{array}$ \\
\hline \multirow{2}{*}{3} & \multirow{2}{*}{ Industry } & $\begin{array}{l}\text { Fuel switch from coal to biomass and natural } \\
\text { gas for cement, iron steel, pulp and paper, } \\
\text { and textiles and fertilizer industries }{ }^{\mathrm{b}}\end{array}$ & $\begin{array}{l}\text { Increasing efficiency of boilers (new } \\
\text { rotary burners) and furnaces (by } \\
\text { preheating fuel) that could save energy } \\
\text { of around } 16 \% \text { by } 2030^{\mathrm{e}}\end{array}$ \\
\hline & & $\begin{array}{l}\text { Modernization of process from wet to dry } \\
\text { kiln in cement industry and increasing } \\
\text { efficiency of boilers and furnace that could } \\
\text { save energy around } 16 \% \text { by } 2030^{\mathrm{b}}\end{array}$ & $\begin{array}{l}\text { Full implementation of maximum } \\
\text { feasible reduction (application of air } \\
\text { pollution control devices) in cement and } \\
\text { iron industry by } 2030^{\mathrm{e}}\end{array}$ \\
\hline \multirow{3}{*}{4} & \multirow{3}{*}{$\begin{array}{l}\text { Biomass open } \\
\text { burning }\end{array}$} & $\begin{array}{l}20 \% \text { reduction of burned area for forest fire } \\
\text { and crop residue open burning in } 2014 \text { and } \\
\text { around } 40 \% \text { in } 2030 \text { as compared to the year } \\
\text { of } 2010^{\mathrm{d}} \text { (National strategic plan } 2010 \text { ) }\end{array}$ & $\begin{array}{l}\text { Forest area burned would not be over } \\
\text { than } 48,000 \text { ha } \mathrm{y}^{-1}(2030)^{\mathrm{g}} \text { (National } \\
\text { master plan) }\end{array}$ \\
\hline & & \multirow{2}{*}{$\begin{array}{l}\text { Zero burning of solid waste by } 2030 \text { due to } \\
\text { improved SW management in most of urban } \\
\text { areas }^{c}\end{array}$} & $\begin{array}{l}\text { Zero burning policy to re-use of crop } \\
\text { residue as bio-energy up to } 25 \% \text { from } \\
\text { total energy demand in } 2030^{\mathrm{g}}\end{array}$ \\
\hline & & & $\begin{array}{l}\text { Amount of solid waste subjected to burn } \\
\text { should be reduced at least } 75 \% \text { through } \\
\text { adequate solid waste management } \\
\text { system in } 2030^{\text {g }}\end{array}$ \\
\hline
\end{tabular}

Source:

${ }^{a}$ Clean Air Asia (CAI, 2010). Roadmap of Euro standard in Asian Countries.

${ }^{\mathrm{b}}$ Indonesia Climate Change Sectoral Roadmap (ICCSR, 2010).

${ }^{\mathrm{c}}$ Energy Sector Management Assistance Program (ESMAP, 2012). Low carbon country studies: Indonesia.

${ }^{d}$ Ministry of Forestry (MoF, 2010). Strategic Plan 2010-2014. Converted from number of hotspot (active fire count) to the burned area.

${ }^{\mathrm{e}}$ Chotichanatawewong and Thongplew (2012). Development trajectory, emission profile and policy actions.

${ }^{\mathrm{f}}$ Department of Alternative Energy Development and Efficiency (DEDE, 2009). Renewable Energy Development

Plant.

${ }^{g}$ National Master Plan of Open Burning in Thailand. PCD (2007). 


\section{Table S2: Summary of projected activity data used for BAU2030}

\begin{tabular}{|c|c|c|c|c|c|}
\hline No & Activity data & Indonesia & Thailand & $\begin{array}{c}2030 / 2007 \text { ratio } \\
\text { (Indonesia) }\end{array}$ & $\begin{array}{c}\text { 2030/2007 ratio } \\
\text { (Thailand) }\end{array}$ \\
\hline 1 & Population & $1998-2007^{\mathrm{a}}$ & $1994-2007^{\mathrm{e}}$ & 1.8 & 1.3 \\
\hline 2 & Total number of motor vehicles & $1998-2007^{\mathrm{b}}$ & $1988-2007^{\mathrm{f}}$ & 3.1 & 2.2 \\
\hline 3 & Total crop production & $1998-2007^{a}$ & $1996-2007^{\mathrm{g}}$ & 1.4 & 1.2 \\
\hline 4 & Livestock population & $1998-2007^{\mathrm{a}}$ & $1996-2007^{\mathrm{g}}$ & 1.8 & 1.7 \\
\hline 5 & Petroleum refinery production & $1998-2007^{\mathrm{c}}$ & $2003-2007^{\mathrm{h}}$ & 2.1 & 3.3 \\
\hline 6 & Mining production & $1998-2007^{\mathrm{c}}$ & $2003-2007^{\mathrm{h}}$ & 2.0 & 1.1 \\
\hline 7 & Aviation landing and take off & $1998-2007^{a}$ & $2003-2007^{i}$ & 2.4 & 1.1 \\
\hline 9 & GDP in forestry sector & $1998-2007^{a}$ & - & 0.7 & - \\
\hline 10 & Forestry area & - & $1992-2001^{\mathrm{e}}$ & - & 0.9 \\
\hline 11 & Energy consumption in power generation & $2000-2007^{c}$ & $1988-2007^{\mathrm{h}}$ & 1.8 & 2.1 \\
\hline 12 & Energy consumption in industrial sector & $2000-2007^{\mathrm{c}}$ & $1988-2007^{\mathrm{h}}$ & 1.9 & 2.0 \\
\hline 13 & Total GDP & \multicolumn{2}{|c|}{$2000-2007$ (all other SEA countries) $^{\mathrm{d}}$} & \multicolumn{2}{|c|}{2.2} \\
\hline
\end{tabular}

Data sources:

a National Bureau of Statistics (BPS, 2008). Indonesia in figure 2008.

${ }^{\mathrm{b}}$ Department of Land Transportation (DLT, 2008). Transportation Statistics 2008.

${ }^{\mathrm{c}}$ Ministry of Energy and Mineral Resources (MEMR, 2008). Key Indicator of Indonesia Energy and Mineral Resources 2008.

d The World Bank (WB, 2008). http://data.worldbank.org/indicator/NY.GDP.PCAP.KD.ZG. Population weighted GDP from other SEA countries and China for the period of 2000-2007 was collected to project to 2030. The GDP growth factor expressed as the ratio of 2030/2007 population weighted GDP was calculated and was used to project emissions for other SEA countries and Southern part of China.

e Thailand National Statistics Office (NSO, 2008).

${ }_{\mathrm{f}}^{\mathrm{f}}$ Ministry of Transportation (DLT, 2008). Transportation Statistics. Department of Land Transport (DLT) (2008).

g Office of Agricultural Economics (OAE, 2008). Agricultural Statistics of Thailand 2008.

h Energy Policy and Planning Office (EPPO, 2008). Statistics database.

${ }^{\mathrm{i}}$ Department of Civil Aviation (DCA, 2008). Statistics report. 

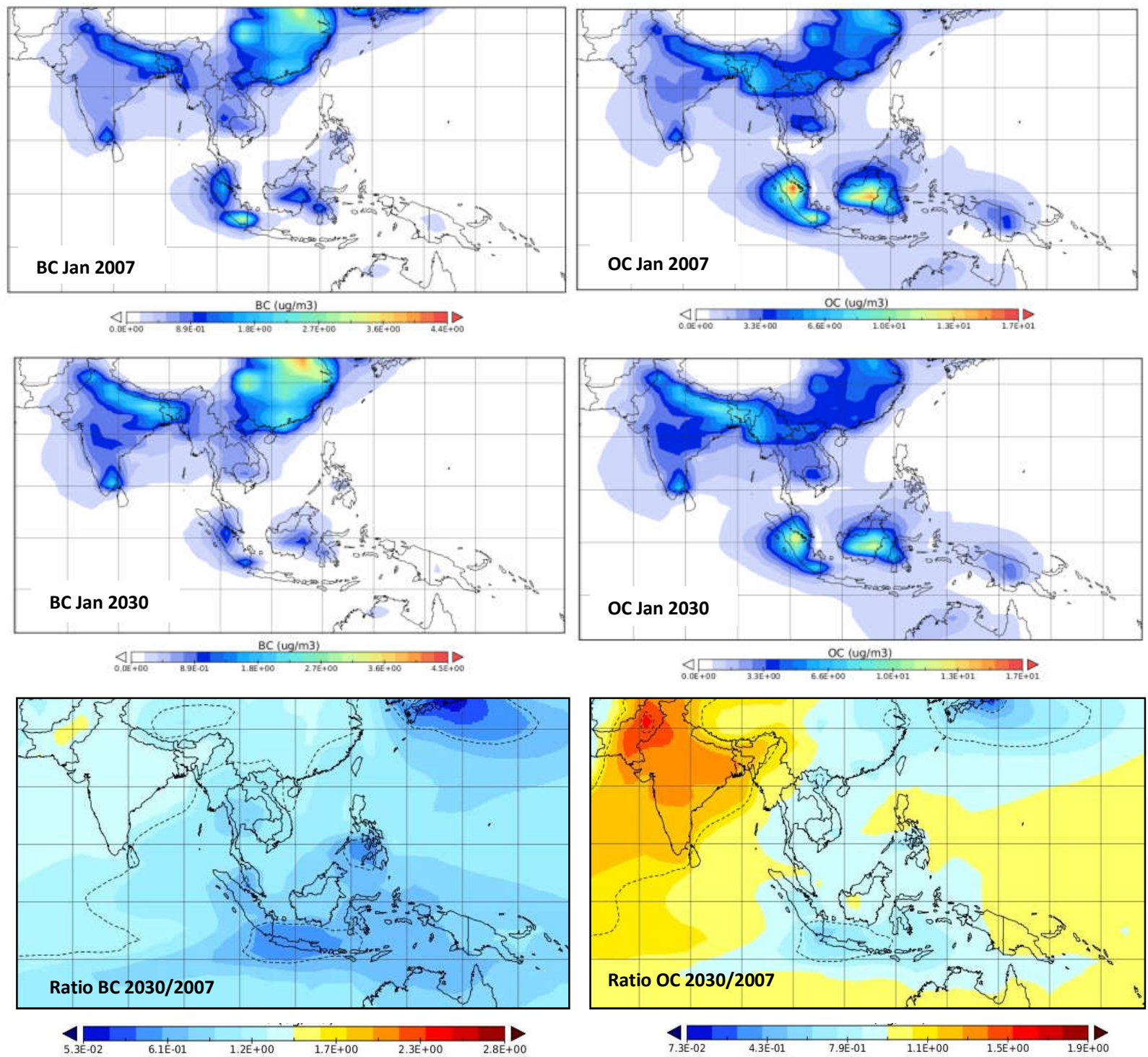

Figure S1: Annual average concentrations of BC and OC obtained from global LMDZ/INCA simulation for 2006 and 2030 and the constructed 2030/2006 ratios for both species (Data from Dr Didier Hauglustaine, through personal communication)

Note: dotted lines show the ratio of 1.0 

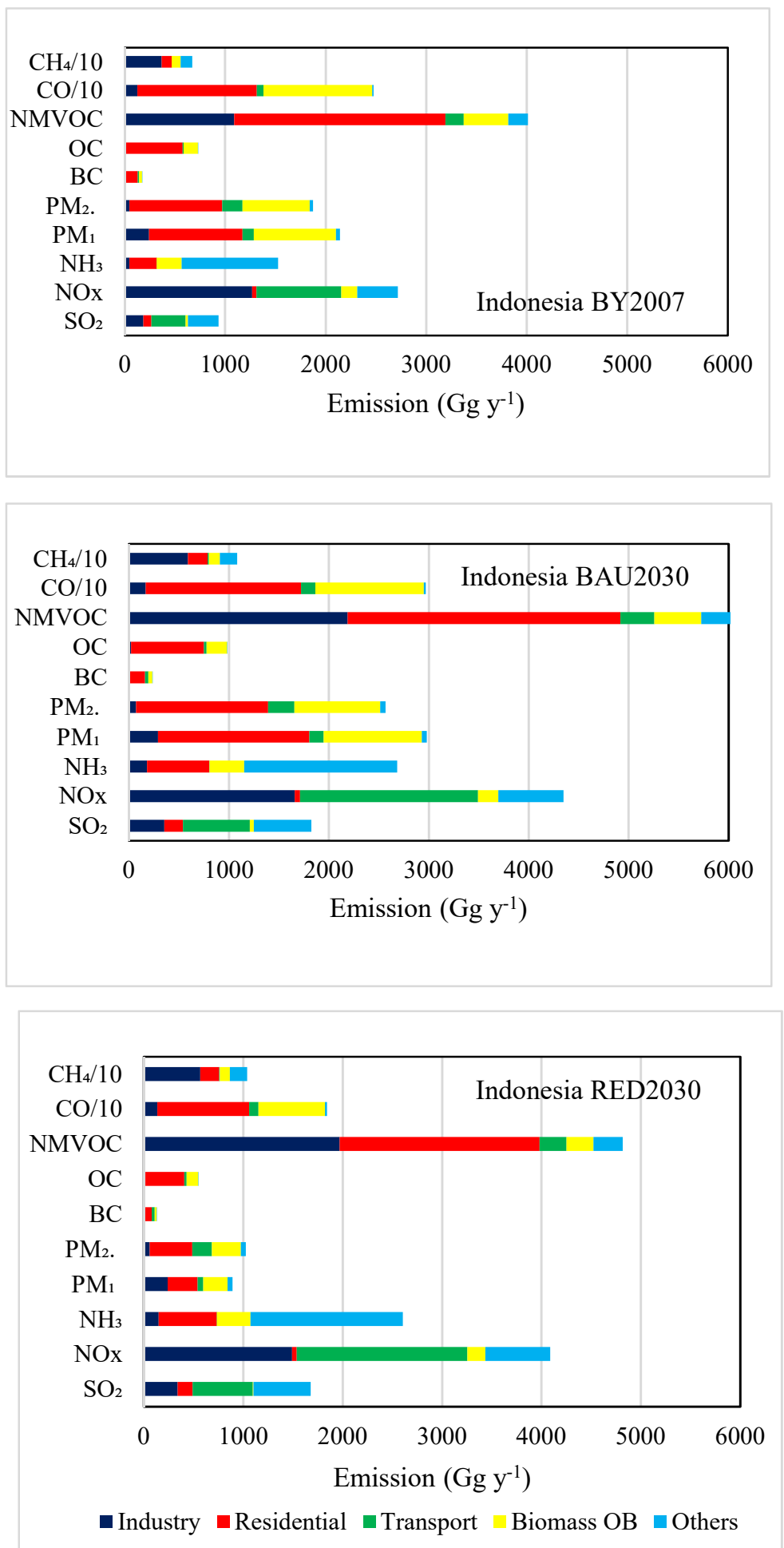

a) Indonesia
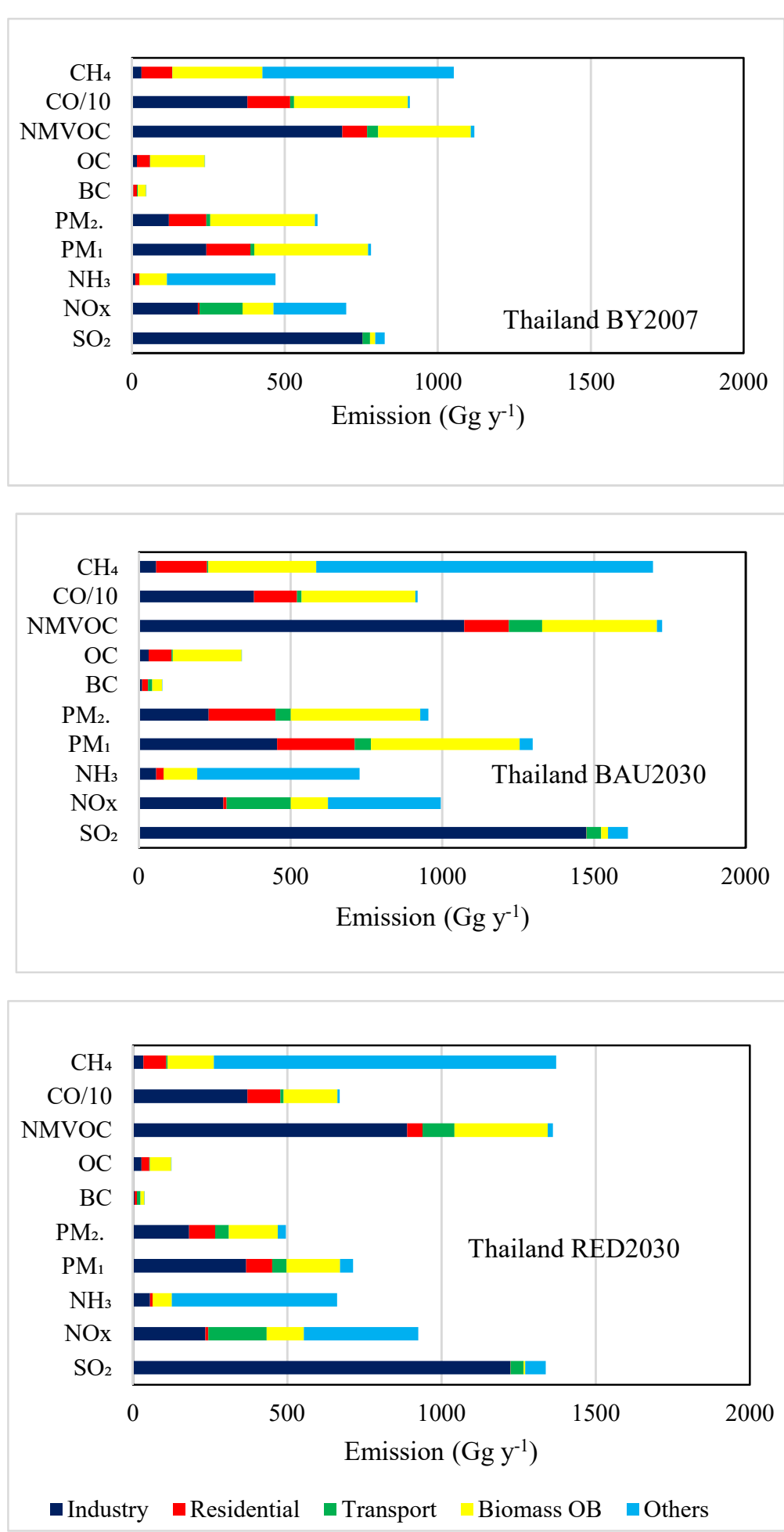

b) Thailand

Figure S2: Sectoral emissions of key species in BY2007, BAU2030 and RED2030 scenarios for Indonesia and Thailand 